\title{
PSYCHOLOGICAL AND PEDAGOGICAL IMPACT ON THE DEVELOPMENT OF MODERN CHILDREN'S CREATIVE ABILITIES
}

\section{Vynohradova V. Ye.}

\section{INTRODUCTION}

Today, the progress of society is aimed not only at the development of technological and technical industries, but also at the development of personality throughout life. The gains in many areas of the state depend on the creativity and creativeness of the people living in it. Accordingly, the problem of creativity, training and education of the creative person and the stimulation of creative work is important in public policy. The experience and successes of the most developed countries in the field of science, manufacturing, new technologies, culture and education indicate the need for a radical restructuring of the system of training and education in the direction of creating conditions for a creative person to freely express his abilities, development in accordance with the makings.

The psychological basis of educational projects and programs for the development of a competitive personality is the principle of selfdevelopment. It integrates the system of principles of personality development formulated in the theory of the origin and formation of the psychics and consciousness of L.S. Vygotskyi, the psychological theory of personality and activity of A.N. Leontyev and S.L. Rubinstein, and the theory of the development of the child's personality L.I. Bozhovych, D.B. Elkonin and others.

In our opinion, a person's awareness of his or her potential opportunities, the prospect of personal and professional growth encourages him or her to a constant experimenting, that is, to creativity.

The consequences of the socio-economic crisis that our state is experiencing is that society today is no longer an institution for the formation of a full-fledged personality, and the family is in a situation of conflict and struggle for existence. In this regard, the need to ensure conditions for the full development of the personality of a child, his abilities, optimal education and training is highlighted. In particular, the 
urgent problem now is the development of creativity, creative abilities, adaptation to new and stressful social conditions through the use of one's own psychological resources.

In the conditions when traditional moral and ethical imperatives are destroyed and new ones are not created, when society does not give social guarantees to a young citizen, a personality is formed with internal conflict, aggressive, incapable of sympathy and empathy, devoid of a sense of duty and responsibility.

Recently, more and more information has appeared about children who are a significant problem for parents and public educational institutions. Their behavior contains non-traditional forms of interaction with parents, teachers and educators. That is, the problem of generations both existed and exists today. This phenomenon was called the theory of generations. In our opinion, attention should be paid to the issues of transformation of old approaches in the educational process. So, now, there arises the question of determining the contradictions that arise between representatives of different generations that are participants of educational processes. And also the question of finding out methods and forms of training that can be effective for new generations comes to the fore.

\section{The impact of generational change on creating new approaches in the education system}

For some time now, teachers, psychologists, philosophers, sociologists and others have been solving the problem of finding new approaches in the educational process for the new generation. Despite the fact that the younger generation has been the subject of psychological and pedagogical research since the end of the 19th century, a question of the phenomenon of the theory of generations remains very relevant today. Fundamental are the approaches of L.S. Vygotskyi, J. Piaget, B.G. Ananyev, G.S. Kostyuk, M.I. Lysyna, A.A. Lublinska, A.V. Zaporozhets, L.A. Wenger, P.Ya. Halperin ${ }^{1}$. The theory of generations in 1991 was created by American scientists N. Hove and V. Strauss. Their study showed that the main difference between generations is their value system. Today, this issue in Ukraine is mainly dealt with by sociologists. O. Borusevvch believes that the study of a "generation" as a sociological category can help

\footnotetext{
1 Методики исследования базовых характеристик участников современного образовательного процесса / М.Р. Мирошкина [и др.]. М., 2015. 95 с., С. 11.
} 
to find ways for the restoration and development of the Ukrainian cultural ethos $^{2}$. These are the directions of its search "through the formation of a scientifically based concept of the intergeneration transmission of traditions", that A. Gorban and I. Kalnoy deal with ${ }^{3}$. And A. Svynarenko stresses the need to implement the Ukrainian ethnos in state policy, management, business and other spheres of life of the Ukrainians ${ }^{4}$.

As for psychologists and teachers, then, unfortunately, there are only occasional studies on finding approaches to the development and training of generation $\mathrm{Y}$ and $\mathrm{Z}$. However, the millennium generation has already grown. These are children who are now between 15 and 36 years old. And the education system is just beginning certain reforms. Some of the teachers who taught back in the days of the Soviet Union were not able to adapt to new conditions and adapt to the generations of children who grew up in the independent Ukraine. From time to time, you can hear from students or parents of students about the authoritarian style of teaching, careful presentation of lectures and literal learning of memory. That is, it is about forming a conformal personality that cannot hold its own position. Therefore, the education and training system that has been in use for several generations is not effective enough today and new approaches to the development of the younger generation should be sought. It should also be noted that the theory of generations today is widely used by psychologists, marketers, sociologists, pedagogues, economists, and managers. After all, having determined the main differences between generations, one can find a universal approach to representatives of all ages. Today of those people living on the planet, six generations are distinguished: generations of winners or GI (born in 1901-1922); silent generation (1923-1942); generations of boomers or baby boomers (1943-1963); generation X (1963-1983); generation Y (1983-2003); generation Z (2003-2023). The main thesis of this theory is the fact that the period of time in which a person was born affects his or her worldview and value system ${ }^{5}$. A person who reaches a certain age does not acquire the

\footnotetext{
${ }^{2}$ Борусевич, О. (2000) Міжпоколіннева трансформація етнічних цінностей : автореф. дис. на здобуття наук. ступеня канд. соц. наук : спец. 22.00 .03 «соціальна структура, соціальні інститути» (р. 15). Київ.

${ }^{3}$ Горбань, А, \& Кальной, И (Eds.). (2012). Поколения в истории: ритмы духовности (p. 440). Симферополь: ИТ «АРИАЛ».

${ }^{4}$ Свинаренко А. (2004) Міжпоколінні особливості колективних ідентифікацій в умовах інтенсивних соціальних змін : автореф. дис. на здобуття наук. ступеня канд. соц. наук : спец. 22.00.03 «соціальна структура та соціальні відносини» (р. 16). Київ.

5 Лумпиева Т.П., Волков А.Ф. Поколение Z: психологические особенности современных студентов. URL: http://ea.donntu.org:8080/handle/123456789/21748.
} 
age values characteristic of this period. This is due to the fact that children who reach the age of their parents do not become the same as they are; their attitude to life is still different ${ }^{6}$. That is, N. Hove and V. Strauss substantiated that every twenty years a new generation appears with a different value system and behavior different from their predecessors. According to the scientists, the dominant influence on the formation of generational values is the parenting model, which is adopted in the family, as well as factors such as political, economic, social and technological events that occurred with children under 11-12 years old ${ }^{7}$. These are the values which influence a person's behavior throughout his or her life attitude to work, views on the world, consumer behavior, and the like . $^{8}$

Today, based on an analysis of modern sources, certain trends can be identified in the formation of psychological characteristics of adolescents belonging to the $\mathrm{Z}$ generation'. It should be noted that scientists observe changes in the age development of the nervous system of the young generation due to the digital revolution. So, the psychophysiological development of each child is subject to the laws of consistent age development, each stage of which prepares him or her for the successful passage of the next one. The flow of information that a modern schoolchild, who is not adapted for children's consciousness, has to consume, provokes increased excitability, sensitivity, restlessness, fussiness and, in extreme cases, hyperactivity. An increase in the number of children diagnosed with ADHD and hyperactivity is observed. At the same time, representatives of the $\mathrm{Z}$ generation learn quickly and also quickly process information, can instantly switch from one type of activity to another, and also act in multitasking conditions. Possession of information and the possibility of its search contributes to the formation of the young people's self-confidence, confidence in their abilities, and forms their own point of view. There is an increase in the number of children diagnosed with ADHD and hyperactivity ${ }^{10}$.

\footnotetext{
6 Зайцева Н.А. Теория поколений: мы разные или одинаковые? // Российские регионы: взгляд в будущее. 2015. № 2 (3). С. 220-236.

Арцимович И.В. Современное поколение: вызовы обществу или времени // Интерактивная наука. 2017. № 12. С. 119-121; Антипов А. Времена года и времена жизни // Russian Valley. URL: http://rugenerations.su/2009/04/30/времена-года-и-времена-жизни; Ожиганова Е.М. Теория поколений Н. Хоува и В. Штрауса. Возможности практического применения // Бизнес-образование в экономике знаний. 2015. № 1. С. 94-97.

8 Зайцева Н.А. Теория поколений: мы разные или одинаковые? // Российские регионы: взгляд в будущее. 2015. № 2 (3). С. 220-236.

${ }_{9}^{9}$ Сапа А.В. Поколение Z - поколение эпохи ФГОС // Продуктивная педагогика. 2015. № 8 (56). С. $2-9$.

${ }^{10}$ Сапа А.В. Поколение Z - поколение эпохи ФГОС // Продуктивная педагогика. 2015. № 8 (56). С. 2-9.
} 
It should be noted that researchers distinguish the following characteristic, the so-called clip-like thinking. This means the ability to perceive the world through short vivid images and messages, for example, through a news feed, short articles, or short video clips ${ }^{11}$.

Practice shows that the average period of concentration of attention of a representative of generation $\mathrm{Z}$ at one object is only eight seconds. In addition, representatives of the $Z$ generation want to see icons, emoticons, pictures replacing text instead of the text ${ }^{12}$.

This state of affairs explains why it is difficult for modern youth to read multivolume works of fiction by classics that have been read by older generations, and thesial literature (checklists, Life hack, step-by-step algorithms, diaries, comics) is a success. The representatives of the $\mathrm{Z}$ generation are growing up in a world in which opportunities have no boundaries, and the time resource is limited. Thus, young people adapted to the need to evaluate and filter vast amounts of information very quickly. The perception and thinking of "digital children" has not become positive or negative, it has changed and acquired a new format which satisfies the needs of the information era of humanity. They differ in the fact that from birth, not yet learning how to speak, they can switch on a computer, tablet or mobile phone to play their favorite game. That is, the $\mathrm{Z}$ generation are children who are influenced by the Internet and modern technologies. They are not used to spending much time with peers in the playground; they are more formed alone with technologies. That is, more and more they are interested in the virtual, not the real world. Quite often they do not know how to work in a team, due to poorly developed communication skills.

Scientists also note that the relationships between parents and children of the $\mathrm{Z}$ generation are friendly, as a rule, there is no authoritarian pressure from parents. The absence of a desire to build a career is observed in the majority of children of this generation. They are not afraid of the world, are rather freedom-loving, like to travel, a part of them like to learn, quickly absorb large amounts of new information. It is clear that they get most of the information from electronic resources. However, as a rule, this knowledge is not deep, but is superficial. However, scientists note that they

\footnotetext{
${ }^{11}$ Азаренок Н.В. Клиповое сознание и его влияние на психологию человека в современном мире // Мат. Всерос. юбилейной науч. конф., посв. 120-летию со дня рождения С.Л. Рубинштейна «Психология человека в современном мире». Том 5 «Личность и группа в условиях социальных изменений» / отв. ред. А.Л. Журавлев. М.: Изд-во «Институт психологии РАН», 2009. С. 110-112.

1230 фактов о современной молодежи: исследование Сбербанка и Validata // Янгспейс. 2017. № 11. Режим доступа: http://youngspace.ru/faq/sberbank-issledovanie-molodezhi.
} 
are interested in complex tasks; they are distinguished by creativity and the ability to solve several problems simultaneously.

However, $\mathrm{Z}$ children generation should to be motivated. They expect quick feedback on their actions. It should be noted that X-parents are not satisfied with the ineffective programs of their children's development and their paternity. Therefore, they are actively involved in the process of developing new programs that meet their requirements, and searching for alternatives in the development of their children. The huge number of startups in the field of education over the past 25 years is clear evidence of this. If 27 years ago private kindergartens and schools did not exist in Ukraine, today in Ukraine we have about 350 private kindergartens and 142 private schools. This suggests that the old principles of education and training do not satisfy the request of modern parents and their children. And the demand is restrained only due to the fact that a large number of parents cannot afford a private kindergarten or school due to the high cost of educational services.

E. Shamis connects the value of childhood with the fact that the $\mathrm{X}$ generation had a real, free, eventful childhood. Therefore, childhood is perceived by the $\mathrm{X}$ generation as the mega-important period of life. That is why its representatives are trying with great responsibility to give the best childhood to their children. In addition, they compensate for the occupation of their parents - baby boomers, who were constantly at work in their childhood. Given the conditions for the $\mathrm{Z}$ generation to be raised by $\mathrm{X}$-parents, we can say that, on the one hand, Z-children grow up in a friendly and trusting atmosphere. They know that their parents will do everything possible for them to be happy, they can share their successes or problems, and they themselves participate in important family issues. Young people respect parents, assimilates family values, knows how to build relationships, they become internally freer, conscious, able to reflect and have a more developed emotional intelligence. On the other hand, X-parents' hyper guardianship affects the formation of a consumer attitude to society and the environment, egocentrism and infantilism in children of the $\mathrm{Z}$ generation. It can be noted that the modern generation are trying to make friends with their parents and this will favorably affect personality development and future formation.

One of the theses of the theory of generations should be noted. It testifies that a thing which is in short supply becomes a value ${ }^{13}$.

${ }_{13}$ Антипов А. Времена года и времена жизни // Russian Valley. URL: http://rugenerations.su/2009/ 04/30/времена-года-и-времена-жизни. 
Accordingly, the $\mathrm{Z}$ generation, immersed in virtual communication, which is fragmented and ignores any spiritual connection between people, lacks live communication, interpersonal direct communication. Spiritual communication becomes the value of the modern youth, hence the desire to be on friendly relations within the family, as well as the value and significance of the family in the whole. Therefore, it is possible to determine a tendency which characterizes modern adolescents: live today, have fun and do work that brings pleasure, joy and a good income, but does not take much time ${ }^{14}$. Young people are not oriented to a long-term professional career, an eight-hour working day and a desire to be a workaholic. The $\mathrm{Z}$ generation live in an endless and rapidly changing flow of information, surrounded by social networks and advertising, calling and cultivating lives on the principle of "here and now". Perhaps that is why modern children think about the nearest future, live live for today and do not think about distant prospects.

In the continuation of the analysis of the leading characteristics of modern children, we pay attention to another important aspect of the theory of generations - cyclicity. That is, the generations that follow each other, for example, $\mathrm{X}$ and $\mathrm{Y}$ generations, have different values and attitudes from each other, but the generations of "great-grandfathers" find their reflection in the generation of "great-grandchildren." The generational cycle is theoretically about 80 years. Based on this, the previous incarnation of $\mathrm{Z}$ is the "silent generation", or "book children", born between 1923 and 1943. The "silent generation" was formed under the conditions of the dangerous Stalinist post-war world. Therefore, they spent their childhood with books, moving away from reality into a completely different ideal art world. We are witnessing a similar situation now. The $\mathrm{Z}$ generation lives in the face of overcoming the deep economic crisis, military events in eastern Ukraine, the annexation of the Crimea, the possible expectation of terrorist acts, in the face of growing information about crime, accidents, and epidemics. They, like the "great-grandfathers" generations, are looking for the opportunity to feel full-fledged free personalities. The world of virtual reality satisfies this need, for modern children it becomes more natural and understandable ${ }^{15}$.

\footnotetext{
1430 фактов о современной молодежи: исследование Сбербанка и Validata // Янгспейс. 2017. № 11. Режим доступа: http://youngspace.ru/faq/sberbank-issledovanie-molodezhi.

15 Чумаков В. По материалам беседы с Е. Шамис и А. Антиповым // Коммерческий директор. 2007. № 11 (23). C. 56-61.
} 
Today, the Internet plays a significant role in the life of the modern youth. It forms views, lifestyle, interests, replaces television, teaches and enables online communication and the like. Children and adolescents are better versed in technology than in human emotions and behavior. According to the doctor of psychological sciences, the candidate of medical sciences psychotherapist M. Sandomyrskyi, if the person-toperson communication had a great influence on a person of previous generations, then for the new generation, most likely, virtual communication will prevail over the real one. He notes that modern young people tend to communicate less with each other, but at the same time they communicate more. They communicate less in social reality and more and more in virtual reality. This tendency, according to the scientist, leads to the autization of the "generation of the future." It should be noted that in autism the author does not understand personality disorder, but its preclinical forms. In this context, autization acts as a way of interacting with the world of people, immersed in themselves from childhood and able to communicate with others, as protection from the problems of a modern lifestyle, as a way to isolate oneself from the world ${ }^{16}$.

Z. Bauman notes that responsibility for modern youth takes on a shortterm, instrumental nature. Representatives of the $\mathrm{Z}$ generation prefer to avoid responsibility or minimize its share both in degree and in time ${ }^{17}$. So, according to N. Zorka, the youth makes a choice in favor of a well-paid job, but not associated with high responsibility ${ }^{18}$. Considering that responsibility implies independence in decision making and choice, then, according to N.N. Zarubina, young people "have an increased tendency to undue risk and underestimation of the possibilities of negative consequences against the background of the prospects for the entry of momentary benefits - pleasure, benefits, and high appreciation from others. Also for the $\mathrm{Z}$ generation, instrumental values are categories such as education and professionalism. This means that the process of qualitatively obtaining knowledge, skills and abilities among the youth is inferior to its result - passing exams and obtaining a diploma, but the profession itself is not of interest and is considered by them as a resource

\footnotetext{
16 Чумаков В. По материалам беседы с Е. Шамис и А. Антиповым // Коммерческий директор. 2007. № 11 (23). С. 56-61.

17 Бауман 3. Текучая современность / пер. с англ.; под ред. Ю.В. Асочакова. СПб.: Питер, 2008. 240 с.

18 Зоркая Н. Современная молодежь: к проблеме «дефектной» социализации // Вестник общественного мнения. 2008. № 4 (96). С. 17-19.
} 
for future success, as a tool that allows you to take "a highly profitable economic niche".

So, an analysis of the values of the $\mathrm{Z}$ generation allows us to identify some trends in the formation of the views of the modern youth. However, these conclusions are enough to understand the difference in the views of older generations and the representatives of $\mathrm{Z}$. For modern youth, the traditional patterns that are provided by older generations can no longer serve as unequivocal guidelines in decision-making on issues of principle $^{19}$. Therefore, it is necessary to develop new approaches and methods of training, development and education in accordance with the needs of modern youth.

\section{Search for innovative psychological and pedagogical approaches for the development of the $Z$ generation children"s creative abilities}

For modern researchers from different scientific fields an important task arises in studying "digital children" and tracking their formation in the future. However, many educators still do not know about the phenomenon of the Z generation. Some use it only as a "tag": it is a "heavy" child. And the question of how to teach, educate and develop this child is more often solved on an intuitive level. Therefore, it is necessary to determine what innovative methods need to be developed so that children who have new psychological characteristics and behaviors to be effective for their development. We are especially interested in the direction of development of creative abilities of talented youth.

If the information on the psychological characteristics of children of the $\mathrm{Z}$ generation and their behavior has recently been significantly disseminated, the question of an effective system of education and training in modern psychological and pedagogical science remains unaddressed. Of course, in order to create a new model of the educational process in higher education or to transform the old one, it is necessary to find out the needs of modern youth and determine the peculiarities of their value system.

However, an analysis of the problem of interaction and training of generations showed that, in the presence of certain approaches to the study of this problem, at the same time, there was a lack of a holistic, systematic

\footnotetext{
19 Сычев А. Поколение Z: те, кто будет после: интервью с Марком Сандомирским. URL: http://hrportal.ru/article/pokolenie-z-te-kto-budet-posle.
} 
scientific and pedagogical understanding of the interaction of different generations as carriers of experience, a certain system of values, means of communication and assimilation of knowledge in the modern educational space. Recently, only some Russian pedagogues have been studying this issue: M.R. Miroshkin, S.B. Tsimbalenko and A.V. Reshetnikova. The issues of intergenerational interaction in the search for new psychological and pedagogical approaches require in-depth research in domestic science.

We conducted a pilot study of the values of first-year students of Taurida National V.I. Vernadsky University. According to the results of the study, it was revealed that students of the "digital generation" have gender differences in the value system. Male students prefer values such as: life wisdom, health, social recognition, the happiness of others, creativity, self-confidence; the girls chose: a happy family life, self-confidence and a materially secured life. The values to which they do not attach importance at all are as follows: cheerfulness, independence, amount of education, honesty, a flexible attitude to shortcomings in oneself and others, rationalism and tidiness.

Regarding the attitude towards creative realization and creativity in general, the position of students was the following. For first-year male students, "creativity" is: human activity aimed at creating something new, completely unique product; development of creativity, creative abilities; human talent, freedom of opinion and favorite activity; this is a unique worldview; activities aimed at expressing oneself, one's thoughts and emotions; this is life itself; an activity which a person enjoys and which he or she performs voluntarily. For female students, "creativity" is: the ability to express their feelings and emotions; Liberty; expression of personality through art; activities aimed at uniqueness and implementation of ideas and creativity; the ability to see beauty; an opportunity to prove oneself; complete freedom of action; sublimation; expression of emotions through anything.

The source of inspiration for the guys is free time, peace and quietness, good weather, a loved person, playing sports and intrinsic motivation to achieve a goal, that is, a search for strength in oneself; free time, support for loved ones, praise. Motivation for creativity for girls can be: the world, the beauty of nature, people around, music, movies, silence, books, dancing, long journeys, communication, the success of others, support of close people; desire to develop, interesting people, beautiful things, love. 
Analyzing the obtained results, we can conclude that freshmen understand creativity as a process of creating a completely new unique product; activities in which a person can express himself; art and talent display; activities that you enjoy. The motivation for this activity is the support of close people, communication, the beauty of nature, the environment and love.

As we can see, the understanding of the concept of creativity and motivation for creativity in boys and girls are similar.

So, based on students' requests, we can develop certain provisions and recommendations for the development of creative abilities of a new generation of personality in the educational process of the university.

Let's define some characteristics of the process of education and training of "digital children".

1. Defining the limits of permitted behavior, the teacher should create conditions for the student to apply a creative approach: allow themselves to establish the "rules of the game" and plan their behavior.

2. To communicate with students as well as adults, showing respect and sincere interest, listen to them, perceive them as wise people who know unknown things.

3. To give detailed instructions and explanations, as well as provide the right to express their opinion in the process of making independent decisions and making conscious choices.

4. Raising the children of the $\mathrm{Z}$ generation is at the same time hard work and privilege: they have a lot to teach, they know a lot not only about themselves, but also about adults, they feel wiles and react negatively to them.

5. In order to be effective, pedagogy must be genuine, professional, full of love. Only such pedagogy is perceived by children of the $\mathrm{Z}$ generation.

6. It should be noted that discipline is extremely important and vital for the $\mathrm{Z}$ generation, since they are creative and mobile in nature, they constantly experiment with different things and experience the limits of what is permitted. Sometimes this behavior can be dangerous, but strict prohibitions do not work with them.

The generation $\mathrm{Z}$ discipline should be based on the development of their spiritual interests, given the following recommendations:

- discuss with the student the behavior that is not clear to you and make sure that he or she has made the right conclusions; 
- react to any situation immediately, avoid dictating tone;

- always keep your promises, accompany the slightest misunderstanding with simple explanations.

Romanyuk L.V. notes that today part of the teachers of Ukrainian universities use active teaching methods, form an atmosphere of dialogue, freedom and creativity at classes. That is, "having mastered the appropriate design algorithm, teachers themselves successfully develop new game techniques and other pedagogical tools that purposefully affect the process of developing a subjective attitude to values among students and pupils of the corresponding age" 20 .

The essence of the implementation of the formation of values and meaning lies in the creation by higher education institutions of conditions for the purpose of self-knowledge, self-development and self-improvement of students' personalities, as well as for self-study, understanding and formation by students of value-semantic foundations of both their personality, their social roles, and future professional activities ${ }^{21}$.

However, far not every existing pedagogical system can provide such conditions for the upbringing and development of the $\mathrm{Z}$ generation children. Most authors agree that education should be alternative and among the most acceptable pedagogical systems they call the Monessori school, Waldorf and other progressive systems. However, they do not have a continuation at a higher school. And, a young man who studied according to an alternative system of education still falls into the standard conditions of universities. Therefore, it may be difficult for him to adapt to a standard learning system and be creative in reproductive learning conditions.

Thus, the above examples of psychological and pedagogical interaction suggest the search for other types, technologies and teaching methods of the younger generation. In our opinion, it is appropriate to turn to a participatory approach. That is, in the educational space this is based on the subject - subjective learning: on the one hand, participants of the educational process, both from teachers, the administration, and students, are objects for transformation and development, and on the other, they are subjects of self-development and self-realization ${ }^{22}$.

\footnotetext{
${ }^{20}$ Романюк Л.В. Становлення цінностей особистості: концептуальна модель та їі методологічний потенціал // Психологія особистості. - Івано-Франківськ. - 2013. - С. 138-148.

21 Романюк Л.В. Становлення цінностей особистості: концептуальна модель та ії методологічний потенціал // Психологія особистості. - Івано-Франківськ. - 2013. - С. 138-148.

22 Мирошкина М.Р. Педагогический потенциал самоорганизации // Сибирский педагогический журнал. - 2014. - № 3. - С. 14-21.
} 
However, the problem of teaching creativity, preparing for professional creative activity is unusual. How to teach something that you yourself don't know, that is, new, creative. From here the idea of "free" education, "spontaneous" development of creativity has arisen. So, it is impossible to teach creativity directly, in the usual sense of the word "learning". We offer the application of an innovative teaching method the group facilitation method.

The founders in the development of facilitation technology as a special process, increase the effectiveness of the group and each individual, are psychologists such as Marvin Weisbord, Ron Lippit, E. SchindlerReinman, Eric Trist, Fred Emery and others. They considered facilitation as an expanded system of flexible impacts on the personality, aimed at the formation of creativity. The methods for finding new solutions are divided into group and individual. Among the group ones, one should note the "brain-storming" of F. Osborne, the synectic of J. Gordon, creative discussion and the like. The socio-psychological aspect of the organization of a creative group has a fundamental role in group methods of searching for new solutions. Among individual or combined methods, one can note the generalized heuristic method of O.M. Polovinkina, the method of garlands of associations, or metaphors, the "seven-time search method" of G.Ya. Bush, the method of "morphological analysis" of F. Zwicky.

Facilitation, as a rule, contains a combination of many methods, however, they are not always focused on a specific result, the main thing in their application is an impetus to creativity. At the classes devoted to the development of creativity, it is necessary, first of all, to create a free playing atmosphere aimed at ensuring comfortable communication, selfconfidence, creative potential of one's own and of the group members. This method is based on such important values as participation, responsibility, teamwork, creativity and the like. The most important principle laid down in it is the empowerment of participants. The basic principles of group facilitation are: participation, group work and cooperation, individual creativity, consensus, reflection, action orientation.

The main goal of facilitation is to increase group efficiency. From the point of view of the result, this helps the group to become better, namely: to improve the quality of decisions, improve team relations, increase personal satisfaction of the group members, and promote the development of creativity and creative abilities of each student. 
The advantages of facilitation are that in working with students their productivity is enhanced. Firstly, this method helps to create a productive working environment and free oneself from formalities, go beyond the ordinary and expand thinking, that is, stimulate creativity: the generation of ideas and practical solutions. Secondly, it allows you to more effectively organize the discussion process and improve the quality of the results. The participants have an understanding that the work results belong to them. In our opinion, this method can be used in such types of educational activities as conducting seminars, trainings and conferences.

We started using the facilitation method at Taurida National V.I.Vernadsky University. It helps to create an atmosphere of free learning and development during the seminar. During facilitation, one can observe how students analyze and realize the need to develop professional qualities, the acquisition of knowledge and skills that they lack. Thanks to this teaching method, the student does not only actively participate in the discussion of seminar issues, but also independently chooses the areas of deepening the knowledge that is interesting and necessary for further professional development. That is, he has the opportunity to build a personal plan for training and development. However, the personal influence of the teacher-facilitator at the lesson is minimal. He sets the format of work, but does not control the process, as during a regular lesson, he gives each student the opportunity to prove himself in accordance with his abilities, capabilities and desires.

The results of such work can be discussed and adjusted at seminars and individual consultations. In order for all the links in controlling the process of developing creative activity of students to work as a whole, an integrated approach to the formation of a creative specialist is necessary. At this the effectiveness and efficiency of pedagogical implementation is ensured by the entire logic of constructing the content of the educational process, the style of training and education, and relevant organizational forms and techniques.

The situation of promoting self-development and self-training (facilitative accompaniment) of a student will turn into facilitating the development of a collective or group subject, is eco-facilitation. Within its framework, access to a collective subject is never open only to one of the subjects of collective interaction; it is possible only as a result of joint coordinated activities to achieve comparable or common goals. 
Another of the psychological and pedagogical approaches corresponds to the principle of environmental friendliness. That is, the main task of the teacher is to create a personality-oriented educational reality. There is enough scientific, pedagogical and psychological literature about a personality-oriented approach. However, in our opinion, its essence may lie in the fact that to obtain knowledge a student can not only develop and acquire knowledge in accordance with his motivation and level of knowledge, but also independently build his own path of development and formation in the profession. So, taking into account the capabilities of the Internet and other modern forms of education, a teacher can accompany the development of a student's personality in accordance with his requests and capabilities. A new everyday life appears, within the framework of which a person can not only draw up unique educational strategies for him, but also form a unique set of professional competencies and qualifications. So, the student is the subject of the educational process, and teachers accompany this process. At the same time, in collaboration with students, a personality-oriented retraining and advanced training of the teaching staff take place.

This regard, a number of characteristics are included in the environmental friendliness criterion of pedagogical actions:

- the well-known principle of "do no harm", which we are used to perceive with regard to doctors and psychologists, today must be correlated with the specific situation of the pedagogical impact, as well as of the one to whom it is directed. First of all, we are talking not only about a combination of external influences, but also about the internal psychological characteristics of a teacher who makes a pedagogical or psychological decision.

- the principle of development - the pedagogical action should take into account the fact that in the process of change and development the teacher also changes, therefore ecological is the action that is social in nature and manifests itself not only, for example, in personal tolerance, but also in the ability to tolerate a situation of uncertainty as part of the educational space.

- pedagogical management, in contrast to the traditional accompaniment of an individual, is transformed into a facilitative process of activating the capabilities of the entire study group as the main subject, 
it is an ecofacilitative accompaniment or ecological systemic help in the self-development of educational ecosystems which are self-developing.

- nonlinearity of ecological pedagogical management who are extremely sensitive to random moments of self-organization of educational ecosystems: the learning effect obtained spontaneously can significantly change the overall strategy of professional or other training (the wellknown "butterfly effect"). Hence the sensitivity to such spontaneous transitions acts as an ecological and tolerant of uncertainty action.

- the principle of self-organization of participants in the educational process in the face of uncertainty and risks of the modern world.

- the principle of actualization of the future: in the face of global uncertainty of the future, the student must be prepared to form and implement his own life project, and not follow the logic of the instructions of the older generation. That is, today a young person needs to have an image of this future, to understand the path to achieving it and to be able to self-organize in order to pass a certain route effectively.

- the principle of correspondence of the content of pedagogical activity to the main characteristics of the generation of children emerges from the basic contradiction of modern pedagogy and the special characteristics of the modern generation of children.

It is also necessary to note that the $\mathrm{Z}$ children should be constantly motivated for each task due to the fact that they do not like to work for the future result. They can be involved in teamwork in a co-working environment. In order to get the best result from their work, it is necessary to give them creative tasks which are maximally interesting for the $\mathrm{Z}$ children themselves. In addition, make sure that they really consider their activities useful to others.

In the future, the research results will allow correlating the values of different generations, to which teachers and students belong. Also, in our opinion, it is necessary to find out ways of gaining knowledge by new generations, which sources are used to obtain information. It is very important to find out common values of different generations and their main differences. So, how educational process in Ukraine should change.

\section{CONCLUSIONS}

Having summarized and analyzed the materials of recent years on the study of the modern $\mathrm{Z}$ generation, it should be noted that this topic is of 
great interest from scientists of different fields: pedagogy, psychology, marketing, philosophy, management, economics and the like. Studies on this issue are underway. They are diverse, multidimensional, which consider the various characteristics of lifestyle and values. It should be noted that the values of the oldest $\mathrm{Z}$ generation representatives are still in the process of formation due to the fact that they have not reached adolescence yet. Z. However, in a year or two, they will become students and teachers will need to look for new approaches and teaching technologies. Therefore, it is necessary to conduct a deeper and more massive study of the generation, which will allow us to complement the socio-psychological characteristics of the $\mathrm{Z}$ generation.

Along with this, a unified theoretical and methodological base has been formed for studying the modern generation, there is a lack of field research, which are provided by current demands of secondary and higher education. In particular, the youngest age groups of children and adolescents remain little studied. The psychological and pedagogical methods and techniques of training, development and upbringing of the new generation are not sufficiently developed. Summing up, we can conclude that modern children are a generation that quickly responded to the needs of the time, adapted to new conditions of life. However, the society did not manage to prepare new models, forms, methods and technologies of the educational system. For the present, this issue will be highlighted in further research.

\section{SUMMARY}

The article reveals the theory of generations of American scientists $\mathrm{N}$. Howe and V. Strauss. The most significant factors of the theory of generations that affect the development of personality, the formation of his or her values have been considered and analyzed. It has been established that the main difference between generations is their value system. It is the analysis of the values of the $\mathrm{Z}$ generation that allows us to identify some tendencies in the formation of the views of the modern youth.

The influence of generational change on the creation of new approaches in the system of higher education has been determined. The basic methods and approaches to the educational impact on students of a new generation have been revealed. Important factors of stimulating the development of creative abilities based on the personality-oriented nature 
of the teacher's interaction with students, the use of psychological and pedagogical technologies that ensure students' independent activity in the process of creative activity and the consistency of educational work with students in a creatively developing environment have been described.

A theoretical search for innovative psychological and pedagogical approaches to the development of creative abilities of "digital children" took place in the article. The directions for the development of the student as a person have been provided. The importance of forming the talents of young leaders has also been noted.

\section{REFERENCES}

1. Азаренок Н.В. Клиповое сознание и его влияние на психологию человека в современном мире // Мат. Всерос. юбилейной науч. конф., посв. 120-летию со дня рождения С.Л. Рубинштейна «Психология человека в современном мире». Том 5 «Личность и группа в условиях социальных изменений» / отв. ред. А.Л. Журавлев. М.: Изд-во «Институт психологии РАН», 2009. С. 110-112.

2. Антипов А. Времена года и времена жизни // Russian Valley. URL: http://rugenerations.

3. Арцимович И.В. Современное поколение: вызовы обществу или времени // Интерактивная наука. 2017. № 12. С. 119-121.

4. Бауман 3. Текучая современность / пер. с англ.; под ред. Ю.В. Асочакова. СПб.: Питер, 2008. 240 с.

5. Безрукова С.Б. Психологические особенности современного поколения. URL: https://nsportal.ru/nachalnaya-shkola/materialy-dlyaroditelei/2016/05/23/psihologicheskie-osobennosti-sovremenn ogo Ван ден Берг Дж. Крутые всегда остаются крутыми / Пер. с анг. СПб., 2012.

6. Гаврилова А.В. Социально-психологические особенности ментальности нового поколения // Вестник Удмуртского университета. Серия «Философия, психология, педагогика». 2016. Т. 26. Вып. 2. С. 58-63.

7. Дудорова Л. Фасилитация корпоративных мероприятий // Корпоративная культура. - 2009. - № 5.

8. Зайцева Н.А. Теория поколений: мы разные или одинаковые? // Российские регионы: взгляд в будущее. 2015. № 2 (3). С. 220-236. 
9. Зоркая Н. Современная молодежь: к проблеме «дефектной» социализации // Вестник общественного мнения. 2008. № 4 (96). C. $17-19$.

10. Кондакова Н.А. Младшее поколение как социальнодемографическая категория: теоретический аспект // Вопросы территориального развития. 2015. Вып. 7 (27). URL: http://vtr.vscc.ac.ru/article/1519/full

11. Лумпиева Т.П., Волков А.Ф. Поколение Z: психологические особенности современных студентов. URL: http:/ea.donntu.org:8080/ handle/123456789/21748

12. Методики исследования базовых характеристик участников современного образовательного процесса / М.Р. Мирошкина [и др.]. M., 2015.95 c.

13. Мирошкина М.Р. Педагогический потенциал самоорганизации // Сибирский педагогический журнал. 2014. № 3. С. 14-21.

14. Мирошкина М.Р. Разные поколения - разный педагогический подход // Школьные технологии. 2014. № 2. С. 8-20.

15. Нечаев Н.Н., Дурнева Е.Е. Цифровое поколение: психологопедагогическое исследование проблемы // Педагогика. 2016. № 1. C. $36-45$.

16. Ожиганова Е.М. Теория поколений Н. Хоува и В. Штрауса. Возможности практического применения // Бизнес-образование в экономике знаний. 2015. № 1. С. 94-97.

17. Пищик В.И. Поколения: социально-психологический анализ ментальности // Социальная психология и общество. 2011. № 2. C. $80-88$.

18. Поколение Selfi e: пять мифов о современной молодежи // ВЦИОМ. Пресс-выпуск № 3265. 13.12.2016. URL: https://wciom.ru/ index.php?id $=236 \&$ uid $=115996$

19. Проект «Новое поколение» Фонда общественного мнения. URL: http://fomgeneration.wordpress.com

20. Решетников О.В. Поколение $\mathrm{Z}$ и недалекое будущее рынка труда // Школьные технологии. М., 2014, № 1.

21. Сапа А.В. Поколение Z - поколение эпохи ФГОС // Продуктивная педагогика. 2015. № 8 (56). С. 2-9. 
22. Сычев А. Поколение Z: те, кто будет после: интервью с Марком Сандомирским. URL: http://hrportal.ru/article/pokolenie-z-tekto-budet-posle/

23. Чумаков В. По материалам беседы с Е. Шамис и А. Антиповым // Коммерческий директор. 2007. № 11 (23). С. 56-61.

24. Шамис Е. «Ослабь хватку» или «Профессиональное родительство» поколения X. URL: https:// rugenerations.su/

25. Шамис Е., Антипов А. Теория поколений. URL: https://www.psycho.ru/library/258.

26. Brooks D. What's the Matter With Kids Today? Not a Thing. The New York Times. Nov. 5. 2000. URL: http://www.nytimes.com/ 2000/11/05/books/what-s-the-matter-with-kids-today-not-a-thing.html (accessed 28.08.2019).

27. Schwarz R. The Skilled Facilitator Approach // The IAF Handbook of Group Facilitation / Ed. by S. Schuman. San Francisco: Jossey-Bass, 2005, P. 21-34.

\section{Information about the author: Vynohradova $V$. Ye. $\operatorname{Dr}(\mathrm{PhD})$, Associate Professor,} Head of the Psychology and Pedagogy Department of the V. I. Vernadsky Taurida National University 33, Ivana Kydri str., Kyiv, 01042, Ukraine 